Original article

\title{
The geographic distribution of Argas (Persicargas) miniatus and Argas (Persicargas) persicus (Acari: Argasidae) in America, with morphological and molecular diagnoses from Brazil, Chile and Cuba
}

\author{
Sebastián Muñoz-Leal ${ }^{\mathrm{a}, *}$, José M. Venzal ${ }^{\mathrm{b}}$, Santiago Nava ${ }^{\mathrm{c}}$, Mercedes Reyes ${ }^{\mathrm{a}}$, Thiago F. Martins ${ }^{\mathrm{a}}$, \\ Romário C. Leite ${ }^{\mathrm{d}}$, Vinicius L.R. Vilela ${ }^{\mathrm{e}}$, Hector R. Benatti ${ }^{\mathrm{a}}$, Daniela Ríos-Rosas ${ }^{\mathrm{f}}$, \\ Darci M. Barros-Battesti ${ }^{g}$, Daniel González-Acuña ${ }^{\text {h }}$, Marcelo B. Labruna ${ }^{a}$ \\ a Departamento de Medicina Veterinária Preventiva e Saúde Animal, Faculdade de Medicina Veterinária e Zootecnia, Universidade de São Paulo, Av. Prof. Orlando \\ Marques de Paiva, 87, Cidade Universitária, São Paulo, SP, 05508-270, Brazil \\ ${ }^{\mathrm{b}}$ Laboratorio de Vectores y Enfermedades Transmitidas, Facultad de Veterinaria, CENUR Litoral Norte, Universidad de la República, Rivera 1350 , CP 50000 Salto, \\ Uruguay \\ ${ }^{\mathrm{c}}$ Instituto Nacional de Tecnología Agropecuaria, Estación Experimental Agropecuaria Rafaela y Consejo Nacional de Investigaciones Científicas y Técnicas, Santa Fe, \\ Argentina \\ d Departamento de Medicina Veterinária Preventiva, Escola de Veterinária, Universidade Federal de Minas Gerais, Belo Horizonte, Minas Gerais, MG, Brazil \\ e Departamento de Medicina Veterinária, Instituto Federal de Educação, Ciência e Tecnologia da Paraíba, IFPB, Campus Sousa, Paraíba, PB, Brazil \\ ${ }^{\mathrm{f}}$ Centro de Biotecnología, Universidad Católica del Norte, Antofagasta, Chile \\ ${ }^{g}$ Departamento de Patologia Veterinária, Faculdade de Ciências Agrárias e Veterinárias, Universidade Estadual Paulista, Campus de Jaboticabal, SP, 14884-900, Brazil \\ h Departamento de Ciencia Animal, Facultad de Ciencias Veterinarias, Universidad de Concepción, Av. Vicente Méndez 595, Chillán (Biobío), 3780000, Chile
}

\section{A R T I C L E I N F O}

\section{Keywords:}

Soft ticks

Argas

North America

South America

\begin{abstract}
A B S T R A C T
High similarity of morphological traits has historically overshadowed the identities and distributions of poultryassociated soft ticks Argas (Persicargas) miniatus and Argas (Persicargas) persicus in America. In order to model the occurrence of both parasites in the continent, in the current study we performed morphological and molecular analyses to identify ticks collected in hen houses from Brazil and northern Chile. Combining these results with literature data, and the examination of Argas allotments deposited in the tick collections "Coleção Nacional de Carrapatos Danilo Gonçalves Saraiva" (Brazil), the "Coleção Acarológica do Instituto Butantan São Paulo" (Brazil), and the "Colección Zoológica de la Academia de Ciencia de Cuba" (Cuba), we present a critical list with the localities where $A$. (P.) miniatus and $A$. (P.) persicus have been reported in the American continent. Our results confirmed the presence of $A$. (P.) miniatus in Brazil and Cuba, and $A$. (P.) persicus in Chile, which in particular, constitutes the first molecularly confirmed report of the later species for South America. Although $A$. $(P$.) $\min$ iatus and $A$. ( $P$.) persicus have been documented in 21 American countries, the identity of some reports must still be considered as uncertain until detailed morphological and/or molecular studies are performed. When contrasted to a Köppen-Geiger climate classification, $A$. $(P$.) miniatus predominantly occurs in equatorial and $A$. ( $P$.) persicus in arid climates. However, until undetermined reports of both species are correctly identified, any conclusion on their geo-climatological occurrence throughout the American continent would be rather speculative.
\end{abstract}

\section{Introduction}

Ticks of the genus Argas Latreille (Argasidae) are haematophagous parasites in all their postembryonic stages and are currently represented by 61 species distributed in all the Zoogeographic Regions of the world (Guglielmone et al., 2010). Based on a morphological approach of immature and mature stages, taxonomic summaries of this genus have proposed to divide most of its specific diversity in six defined subgenera, namely Argas, Carios, Chiropterargas, Microargas, Persicargas, Secretargas and an undefined subgenus referring to Argas bureschi Dryenski 1957 (Hoogstraal, 1985). Particularly, the Argas (Persicargas) group is composed by 16 ornithophilous species phenotypically similar to each other (Hoogstraal, 1985; Estrada-Peña et al., 2003), and well adapted to parasitize domestic birds (Hoogstraal, 1956;

\footnotetext{
* Corresponding author.

E-mail address: munoz-leal@usp.br (S. Muñoz-Leal).
} 
Kohls et al., 1970), to which they can transmit pathogenic eubacteria (Burroughs, 1947; Zaher et al., 1977; Lisbôa et al., 2009) and viruses (Hoogstraal, 1985).

Argas (Persicargas) miniatus was insufficiently described by Koch (1844) from post-larval stages collected in Guyana (Demerara region), and its identity remained problematical until Kohls et al. (1970) reexamined the type specimens. Based on the anatomy of the peripheral integumental cells of two damaged specimens, these authors concluded that $A$. (P.) miniatus was a valid taxon, and redescribed the species from previous treatments as a morphological variety (i.e. var. miniatus and var. dissimile) (Neumann, 1904; Aragão, 1938) and a synonym of $A$. (P.) persicus (Nuttall et al., 1908). In that same work, by the examination of several collections of immature and mature Argas from American localities, the authors presented the distribution of $A$. $(P$.) miniatus, including Brazil, Colombia, Guyana, Panama and Trinidad and Tobago (Kohls et al., 1970). The last morphologically confirmed report of this tick species was made from larvae, nymphs and adults collected in Rio Grande do Sul State in Brazil (Evans et al., 2000). Yet, $A$. (P.) miniatus has been also reported from Venezuela (Vogelsang and Dias, 1953), Cuba (De La Cruz, 1974), Puerto Rico (Capriles and Gaud, 1977), Jamaica and the United States (Keirans, 1984).

The tick $A$. ( $P$.) persicus was described by Oken (1818) from poultryassociated specimens collected in Iran, yet subsequent reports put in evidence a transcontinental distribution, almost always in association to domestic chicken (Hoogstraal, 1956). To date, A. (P.) persicus has documented reports in all the Zoogeographic Regions of the world with the exception of Antarctica, including the majority of African countries (Hoogstraal, 1956; Cumming, 1999), Australia (Petney et al., 2004), China (Chen et al., 2010), Italy (Pantaleoni et al., 2010) and India (Keirans, 1984). In America, morphological studies have identified this tick from specimens collected in the United Sates, Paraguay (Kohls et al., 1970) and Argentina (Nava et al., 2004). Still uncertain are the reports from Cuba (De La Cruz 1976) and particularly from Chile, where a morphological variety named as $A$. (P.) persicus var. porteri and $A$. (P.) persicus were documented from the Metropolitan Region and Calama, respectively (Lahille, 1915; Porter, 1928). Both Chilean records were subsequently considered as possible misidentifications with Argas (Argas) neghmei Kohls \& Hoogstraal 1961 (Kohls and Hoogstraal, 1961).

The study of the larval phenotype is crucial in order to separate species in the Argasidae family (Hoogstraal, 1985; Klompen, 1992), and might constitute a suitable approach to report new or confirm doubtful records for $A$. (P.) miniatus and $A$. (P.) persicus in America. While the morphology of nymphs and adult stages has shown to be less informative, some features of the dorsal integument constitute useful discrete characters for a specific diagnosis in the Argas genus. In order to confirm the identity of Argas ticks associated with domestic chicken, in this study we combine morphological and molecular analyses of immature and mature specimens collected in chicken houses from several states of Brazil, the North of Chile and Cuba. Additionally, we present a map with the current distribution and the identity status of the analyzed species in America.

\section{Material and methods}

\subsection{Examined material}

Two nymphs, six males and one female collected in Calama $\left(22^{\circ} 27^{\prime} \mathrm{S} ; 68^{\circ} 54^{\prime} \mathrm{W}\right.$, elevation $\left.2775 \mathrm{~m}\right)$, Antofagasta Region, Chile, date of collection 03 December 2014; 16 larvae, 41 nymphs, 25 females and 22 males collected in Santa Teresinha $\left(07^{\circ} 05^{\prime} \mathrm{S}\right.$; $37^{\circ} 26^{\prime} \mathrm{W}$; elevation $303 \mathrm{~m}$ ), Paraiba State, Brazil, date of collection April 2014; and 13 nymphs, 11 females, and five males collected in Brasília (15 37'S; $47^{\circ} 56^{\prime} \mathrm{W}$, elevation $1250 \mathrm{~m}$ ), Distrito Federal, Brazil, date of collection 23 October 2016. All these collections of immature and mature soft ticks were made during daytime inside chicken houses by examining fissures in wooden and concrete-made structures. Subsequently, ticks were transported alive to the laboratory and engorged females were placed in an incubator with $25{ }^{\circ} \mathrm{C}$ and $80 \%$ of relative humidity in order to obtain ovipositions. In addition to this field-collected material, we examined Argas allotments deposited in the three following tick collections: Coleção Nacional de Carrapatos Danilo Gonçalves Saraiva (CNC), Brazil: CNC-878 (two females, four males), CNC-1153 (ten larvae, seven nymphs, seven females, six males), CNC-1154 (five nymphs, ten females, ten males), and CNC-2576 (one nymph, three males, two females); Coleção Acarológica do Instituto Butantan, São Paulo (IBSP), Brazil: IBSP-731 (five nymphs, four females, one male), IBSP-803 (two females, one male), IBSP-863 (one female, two males), IBSP-937 (two nymphs, 12 females, ten males), IBSP-1267 (two nymphs, four females), IBSP-1269 (26 females, ten males), IBSP-1279 (seven females, two males), IBSP-1746 (two females, seven males), IBSP-4214 (seven nymphs, six females, five males), IBSP-4317 (28 nymphs, 18 females, 12 males), IBSP-4513 (one nymph, ten females, one male), IBSP-5954 (two males), IBSP-9251 (two females, one male), and IBSP-9934 (one nymph, two males); and the Colección Zoológica de la Academia de Ciencia de Cuba (CZACC), Cuba: N 10704 (one nymph, nine females, six males), and $\mathrm{N}^{\circ} 10734$ (four nymphs, seven females, eight males).

\subsection{Morphological analyses}

Two cohorts of ten laboratory-reared larvae, each one obtained from a unique female per locality, and ten larvae, 12 females and one male from the CNC were clarified in a $20 \% \mathrm{KOH}$ solution, and mounted in slides using Hoyer's medium. In order to visualize the setal pattern with detail and to compare with the original description of other Argasinae, the capitulum of adult specimens was mounted apart from the idiosoma, following the dissection methodology proposed by Cooley and Kohls (1944). Morphological characters of slide-mounted larvae (Fig. 1) and adults were observed under light microscopy and measured above micrographs using the software Image-Plus Pro v5.1. Post-larval specimens from the CNC, CZACC and IBSP were examined using a SteREO Discovery V12 stereomicroscope and measured with the software ZEN 2 pro. All measurements are given in millimeters with the standard deviation followed by the range in parenthesis. We adopted morphological definitions of Sonenshine et al. (1962) for larvae of Argas genus, which consider that only the subgenus Chiropterargas has dorsolateral setae arranged in an anterior and posterior groups. As a clear anatomical definition of both groups of setae is not specified either for $A$. (P.) miniatus or A. (P.) persicus, we did not consider these characters in our study and rather obtained averages of dorsolateral setae.

In order to discriminate the relationship between morphologically similar species, obtained measures of unengorged larvae were submitted to a principal component analysis (PCA) based on Pearson correlation matrix for 40 morphological variables (Table 1). Measurements of Argas (Persicargas) keiransi Estrada-Peña, Venzal \& González-Acuña 2003 were also included in the comparisons.

To observe in detail morphological characters with specific significance, one female of the CZACC was prepared for electron microscopy photographs following Corwin et al. (1979). Subgenus level determination using larval stages followed Kaiser et al. (1964). Species level identification were performed by comparing the obtained morphological and morphometrical data with original descriptions (Kohls and Hoogstraal, 1961; Estrada-Peña et al., 2003) and redescriptions of Argasinae from America (Kohls et al., 1970).

\subsection{Molecular tools}

To confirm morphological diagnoses, DNA extraction using the Guanidine Isothiocyanate technique (Sangioni et al., 2005) was individually performed in three females, three nymphs and two larvae from Calama (Chile), one male and two larvae from Santa Teresinha 


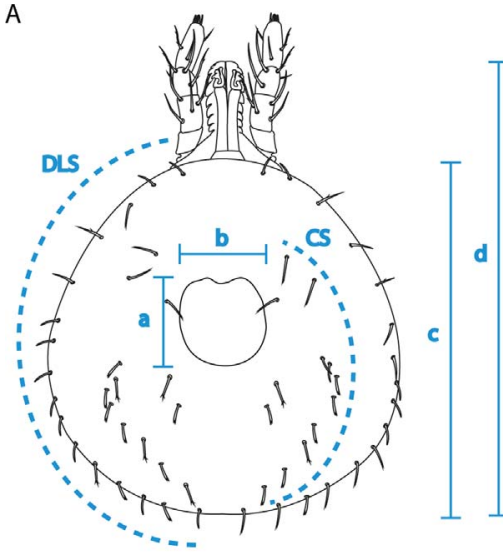

C

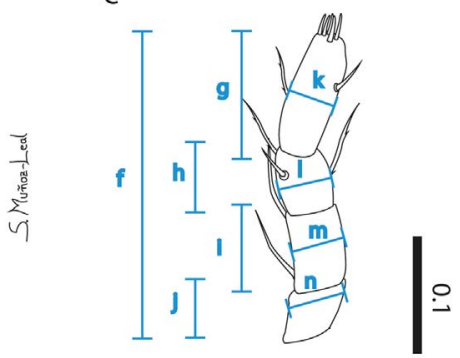

B

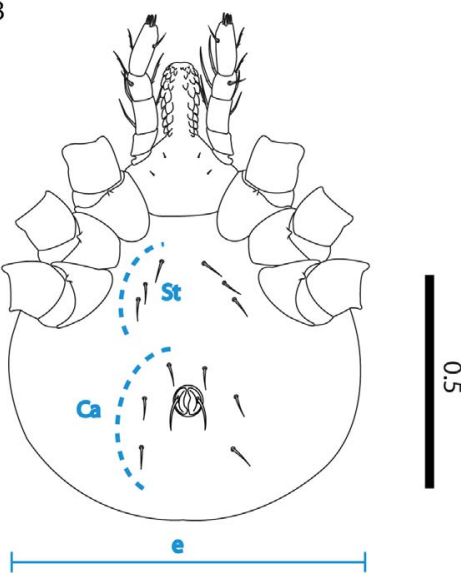

D

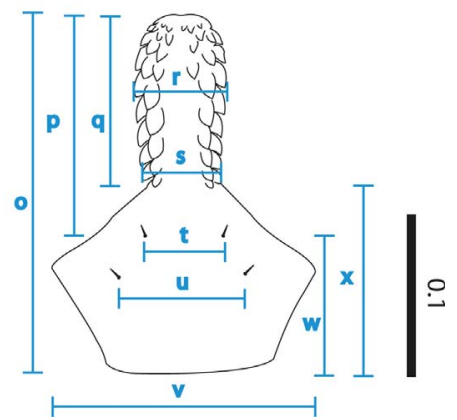

Fig. 1. Measurements and setal groups of unengorged larval stages examined in this study (light blue). (A) Dorsal view. Dorsal plate: (a) length, (b) width. Body: (c) length not including capitulum, (d) length including capitulum. (B) Ventral view: (e) body width. (C) Palpus: (f) total length; length of articles: (g) article I, (h) article II, (i) article III, and (j) article IV. Width of articles: (k) article I, (l) article II, (m) article III, and (n) article IV. (D) Ventral capitulum: (o) total length; hypostome: (p) length measured to ph1, (q) length measured to insertion, (r) middle width, and (s) base width; basis capitulum: (t) distance between ph1 setae, (u) distance between ph2 setae, ( $v$ ) width, (w) length to insertion of hypostome, and (x) length to insertion of hypostome. Groups of setae are denoted with a doted line. Scale bars are given in mm. Abbreviations: DLS, dorsolateral setae; CS, central setae; St, sternal setae; Ca, circumanal setae. (For interpretation of the references to colour in this figure legend, the reader is referred to the web version of this article.)
(Brazil), one female and one nymph from Brasilia (Brazil), two females and six males from the CNC (Brazil), and one female and one nymph from the CZACC (Cuba). A conventional PCR to amplify a $\approx 460$-bp fragment of the tick mitochondrial 16S rRNA gene was performed (Mangold et al., 1998). Expected size amplicons were purified with ExoSAP-IT ${ }^{\circ}$ and further sequenced using the BigDye ${ }^{\circ}$ Terminator v3.1 Cycle Sequencing (Applied Biosystems, Austin, USA) in an ABI automated sequencer (Applied Biosystems/Thermo Fisher Scientific, model ABI 3500 Genetic Analyzer, Foster City, CA) with the same primers used for PCR. Generated sequences were assembled and primer-trimmed with Geneious R9 software (Kearse et al., 2012), and then submitted to BLAST analyses (www.ncbi.nlm.nih.gov/blast) in order to infer closest similarities with other argasid species available in GenBank.

\subsection{Phylogenetic analysis}

An alignment of a partial fragment of the 16S rDNA mitochondrial gene was constructed with 19 Argas sequences retrieved from GenBank (AB819157, AF001401, AF001402, AF001403, AF001404, AY436768, AY436772, DQ295778, DQ295781, EU283344, GU355921, GU451248, KC769587, KC769590, L34305, L34321, NC019642, NC029175, and U95863), and eight obtained in the present study. The sequences were edited using BioEdit Sequence Alignment Editor (Hall, 1999), with manual edition whenever necessary, and aligned with the program Clustal W (Thompson et al., 1994). Phylogenetic relationships were assessed with the maximum-likelihood (ML) method and the best-fitting substitution model was determined with the Bayesian Information Criterion using MEGA 5 (Tamura et al., 2011). GTR model was chosen to create ML trees. Branch support was tested by bootstrap analysis using 1000 replicates. Sequences of Ornithodoros brasiliensis Aragão, 1923 (GU198368) and Ornithodoros rostratus Aragão, 1911 (DQ295780) were used as out-group.

\subsection{Literature revision and mapping}

We listed in a table all the documented reports of $A$. $(P$.$) miniatus$ and A. (P.) persicus for America published until 2016, including unpublished data from the CNC, IBSP and original records of this study. Reports for the United States listed by Bishopp (1941), Cooley and Kohls (1944), and Bishopp and Trembley (1945) were not included, since Kohls et al. (1970) synonymized the majority of its referred collections either with Argas (Persicargas) radiatus Raillet, 1893 or Argas (Persicargas) sanchezi, Dugès 1887. As immature and mature stages of $A$. (P.) miniatus and $A$. (P.) persicus are morphologically closely related, some reports have been considered as possible misidentifications (Kohls et al., 1970; Guglielmone and Nava, 2005). Therefore, we regarded as valid all the localities where the identification of ticks was based either on a molecular or on an explicit morphological analysis, noting the specific characters that separate both Argas (Persicargas) species. Reports lacking this methodology were considered as pending confirmation. Geographical coordinates of non-georeferenced localities were obtained using GEOLocate v.3.21 (Rios and Bart, 2010). When the exact locality of tick collection was not given in the original article, geographic coordinates for the centroid of the country or administrative division indicated as geographic reference in each published record, were calculated based in shapes files retrieved from DIVA-GIS (2011) using the software QGIS 2.16.2 (Quantum GIS Devolpment Team, 2016). Subsequently, all the compiled locations were plotted over a Köppen-Geiger climate classification map (Kottek et al., 2006) based on the R-code given by Rubel et al. (2017).

\section{Results}

\subsection{Morphological study}

By the morphological analysis of 30 slide-mounted larvae, six slidemounted females, late-stage nymphs and adult specimens, two species 
Table 1

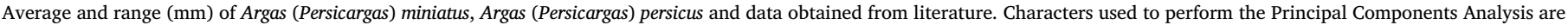
denoted with an asterisk.

\begin{tabular}{|c|c|c|c|c|c|}
\hline & \multicolumn{3}{|l|}{ A. (P.) miniatus } & \multicolumn{2}{|l|}{ A. (P.) persicus } \\
\hline & Paraiba State, Brazil (This study) & $\begin{array}{l}\text { Espírito Santo State, Brazil (This } \\
\text { study) }\end{array}$ & $\begin{array}{l}\text { Kohls et al. } \\
\text { (1970) }\end{array}$ & Calama, Chile (This study) & $\begin{array}{l}\text { Kohls et al. } \\
(1970)\end{array}$ \\
\hline Feeding status & Unengorged & Unengorged & Unengorged & Unengorged & Unengorged \\
\hline $\begin{array}{l}\text { Body length including } \\
\text { capitulum* }\end{array}$ & $0.892 \pm 0.015(0.871-0.913)$ & $0.881 \pm 0.010(0.866-0.896)$ & $0.760-0.870$ & $0.975 \pm 0.024(0.944-1.022)$ & $0.950-0.980$ \\
\hline $\begin{array}{l}\text { Body length not including } \\
\text { capitulum* }\end{array}$ & $0.603 \pm 0.012(0.586-0.597)$ & $0.605 \pm 0.011(0.587-0.622)$ & - & $0.764 \pm 0.013(0.741-0.783)$ & - \\
\hline Body width* & $0.614 \pm 0.010(0.597-0.629)$ & $0.624 \pm 0.022(0.582-0.645)$ & $0.530-0.730$ & $0.788 \pm 0.019(0.762-0.819)$ & $0.680-0.740$ \\
\hline Dorsal plate: form & Oval & Oval & Oval & Circular & Circular \\
\hline Dorsal plate: length* & $0.200 \pm 0.007(0.187-0.211)$ & $0.203 \pm 0.007(0.190-0.211)$ & $0.188-0.220$ & $0.163 \pm 0.014(0.143-0.185)$ & $0.200-0.240$ \\
\hline Dorsal plate: width* & $0.159 \pm 0.004(0.154-0.166)$ & $0.155 \pm 0.006(0.147-0.169)$ & $0.148-0.180$ & $0.171 \pm 0.008(0.158-0.182)$ & $0.180-0.200$ \\
\hline Dorsal setae: total pairs* & $28-29$ & $28-29$ & $25-31$ & $26-28$ & $26-29$ \\
\hline $\begin{array}{l}\text { Dorsal setae: dorsolateral } \\
\text { pairs* }\end{array}$ & 14 & 14 & 14 & 15 & $14-16$ \\
\hline Dorsal setae: central pairs* & $14-15$ & $14-15$ & $11-17$ & $11-13$ & $11-13$ \\
\hline DAL setae media & - & - & 0.049 & - & 0.038 \\
\hline DPL setae media & - & - & 0.070 & - & 0.039 \\
\hline DL setae media & $0.052 \pm 0.002(0.051-0.055)$ & $0.051 \pm 0.002(0.048-0.054)$ & - & $0.041 \pm 0.001(0.040-0.043)$ & - \\
\hline C setae media* & $0.038 \pm 0.001(0.036-0.040)$ & $0.037 \pm 0.002(0.033-0.039)$ & - & $0.042 \pm 0.002(0.040-0.044)$ & - \\
\hline Ventral setae (pairs): total & $6+$ anal pair & $6+$ anal pair & $6+$ anal pair & $6+$ anal pair & $6+$ anal pair \\
\hline Sternal setae: St1* & $0.045 \pm 0.003(0.040-0.049)$ & $0.046 \pm 0.002(0.041-0.049)$ & - & $0.043 \pm 0.003(0.039-0.047)$ & - \\
\hline Sternal setae: St2* & $0.047 \pm 0.002(0.044-0.050)$ & $0.047 \pm 0.004(0.042-0.052)$ & - & $0.043 \pm 0.003(0.038-0.047)$ & - \\
\hline Sternal setae: St3* & $0.048 \pm 0.005(0.034-0.052)$ & $0.049 \pm 0.004(0.043-0.057)$ & - & $0.043 \pm 0.002(0.039-0.047)$ & - \\
\hline Circumanal setae: $\mathrm{Ca} 1 *$ & $0.046 \pm 0.005(0.038-0.053)$ & $0.046 \pm 0.004(0.040-0.052)$ & 0.046 & $0.053 \pm 0.002(0.051-0.057)$ & 0.049 \\
\hline Circumanal setae: $\mathrm{Ca} 2 *$ & $0.049 \pm 0.004(0.041-0.056)$ & $0.047 \pm 0.004(0.041-0.053)$ & 0.048 & $0.049 \pm 0.005(0.040-0.056)$ & 0.045 \\
\hline Circumanal setae: $\mathrm{Ca} 3 *$ & $0.049 \pm 0.005(0.037-0.054)$ & $0.046 \pm 0.004(0.038-0.053)$ & 0.045 & $0.051 \pm 0.004(0.042-0.055)$ & 0.048 \\
\hline Posteromedian setae: Pms & absent & absent & absent & absent & absent \\
\hline Postcoxal setae: Pc & absent & absent & absent & absent & absent \\
\hline Anal plate setae: As & $0.052 \pm 0.005(0.037-0.054)$ & $0.053 \pm 0.005(0.046-0.063)$ & - & $0.067 \pm 0.005(0.060-0.077)$ & - \\
\hline Length of basis capituli ${ }^{\mathrm{a}} *$ & $0.122 \pm 0.006(0.112-0.132)$ & $0.122 \pm 0.008(0.110-0.133)$ & - & $0.113 \pm 0.007(0.104-0.126)$ & - \\
\hline Length of basis capituli ${ }^{\mathrm{b}}$ * & $0.182 \pm 0.011(0.169-0.200)$ & $0.180 \pm 0.008(0.163-0.191)$ & - & $0.145 \pm 0.007(0.130-0.154)$ & - \\
\hline Length of capituli* & $0.340 \pm 0.007(0.326-0.350)$ & $0.337 \pm 0.008(0.323-0.348)$ & $0.300-0.340$ & $0.308 \pm 0.007(0.296-0.319)$ & 0.310 \\
\hline Width of basis capituli* & $0.269 \pm 0.008(0.256-0.279)$ & $0.272 \pm 0.012(0.241-0.281)$ & $0.200-0.230$ & $0.230 \pm 0.008(0.219-0.241)$ & $0.200-0.240$ \\
\hline Posthypostomal setae Ph1 & $0.007 \pm 0.001(0.006-0.008)$ & $0.007 \pm 0.002(0.004-0.009)$ & 0.006 & 0.005 & 0.004 \\
\hline Posthypostomal setae Ph2 & $0.009 \pm 0.002(0.006-0.010)$ & $0.009 \pm 0.002(0.007-0.012)$ & 0.006 & 0.005 & 0.004 \\
\hline Distance Ph1-Ph1 & $0.071 \pm 0.003(0.065-0.075)$ & $0.074 \pm 0.002(0.069-0.078)$ & 0.084 & $0.076 \pm 0.004(0.067-0.079)$ & 0.077 \\
\hline Distance $\mathrm{Ph} 2-\mathrm{Ph} 2$ & $0.116 \pm 0.005(0.109-0.123)$ & $0.121 \pm 0.005(0.113-0.128)$ & 0.131 & $0.122 \pm 0.005(0.116-0.130)$ & 0.138 \\
\hline Palpal length* & $0.262 \pm 0.006(0.251-0.270)$ & $0.263 \pm 0.006(0.250-0.273)$ & $0.230-0.260$ & $0.281 \pm 0.006(0.268-0.287)$ & $0.270-0.280$ \\
\hline Length article I* & $0.054 \pm 0.007(0.040-0.063)$ & $0.053 \pm 0.004(0.048-0.059)$ & $0.052-0.068$ & $0.055 \pm 0.004(0.049-0.064)$ & $0.056-0.080$ \\
\hline Length article $\mathrm{II}^{*}$ & $0.071 \pm 0.006(0.059-0.079)$ & $0.070 \pm 0.003(0.063-0.073)$ & $0.060-0.076$ & $0.073 \pm 0.006(0.068-0.084)$ & $0.068-0.076$ \\
\hline Length article III* & $0.054 \pm 0.004(0.049-0.061)$ & $0.051 \pm 0.002(0.047-0.054)$ & $0.056-0.064$ & $0.065 \pm 0.003(0.061-0.070)$ & $0.056-0.068$ \\
\hline Length article IV* & $0.103 \pm 0.003(0.097-0.107)$ & $0.104 \pm 0.003(0.099-0.109)$ & $0.096-0.120$ & $0.117 \pm 0.005(0.109-0.128)$ & $0.116-0.128$ \\
\hline Width artcile I* & $0.047 \pm 0.005(0.039-0.056)$ & $0.046 \pm 0.004(0.041-0.053)$ & - & $0.064 \pm 0.005(0.057-0.075)$ & - \\
\hline Width article II* & $0.050 \pm 0.002(0.047-0.054)$ & $0.054 \pm 0.004(0.050-0.062)$ & - & $0.050 \pm 0.003(0.048-0.057)$ & - \\
\hline Width article III* & $0.050 \pm 0.003(0.044-0.053)$ & $0.051 \pm 0.002(0.047-0.054)$ & - & $0.049 \pm 0.002(0.046-0.052)$ & - \\
\hline Width article IV* & $0.044 \pm 0.002(0.042-0.048)$ & $0.044 \pm 0.002(0.041-0.047)$ & - & $0.043 \pm 0.001(0.040-0.045)$ & - \\
\hline $\mathrm{N}^{\circ}$ setae article I & 0 & 0 & 0 & 0 & 0 \\
\hline $\mathrm{N}^{\circ}$ setae article II & 5 & 5 & 5 & 5 & 5 \\
\hline $\mathrm{N}^{\circ}$ setae article III & 4 & 4 & 4 & 4 & 4 \\
\hline $\mathrm{N}^{\circ}$ setae article IV & 12 & 12 & 12 & 12 & 12 \\
\hline Hypostome $e^{c} *$ & $0.221 \pm 0.008(0.205-0.231)$ & $0.217 \pm 0.005(0.208-0.228)$ & - & $0.197 \pm 0.005(0.192-0.206)$ & - \\
\hline Hypostome $^{\mathrm{d}}$ & $0.161 \pm 0.006(0.148-0.169)$ & $0.156 \pm 0.006(0.146-0.168)$ & - & $0.161 \pm 0.003(0.157-0.165)$ & - \\
\hline Hypostome $^{\mathrm{e} *}$ & $0.161 \pm 0.006(0.148-0.169)$ & $0.156 \pm 0.006(0.146-0.168)$ & $0.140-0.160$ & $0.161 \pm 0.003(0.157-0.165)$ & 0.168 \\
\hline Hypostome: base width* & $0.093 \pm 0.008(0.082-0.108)$ & $0.097 \pm 0.004(0.088-0.103)$ & - & $0.077 \pm 0.005(0.069-0.083)$ & $0.080-0.084$ \\
\hline Hypostome: middle width* & $0.095 \pm 0.003(0.090-0.100)$ & $0.089 \pm 0.005(0.082-0.096)$ & - & $0.082 \pm 0.003(0.077-0.089)$ & - \\
\hline Apex & blunt & & blunt & blunt & blunt \\
\hline $\begin{array}{l}\text { Apical dental formula } \\
\text { (corona)* }\end{array}$ & $3 / 3-4 / 4$ & $3 / 3-4 / 4$ & $3 / 3$ & $3 / 3$ & $3 / 3$ \\
\hline Median dental formula* & $2 / 2$ & $2 / 2$ & $2 / 2$ & $2 / 2$ & $2 / 2$ \\
\hline Basal dental formula* & $2-2$ & $2-2$ & $2 / 2$ & $2 / 2$ & $2 / 2$ \\
\hline $\begin{array}{l}\text { Denticles in hypostomal row } \\
1^{*}\end{array}$ & $7-9$ & $7-8$ & $8-11$ & $9-10$ & $9-10$ \\
\hline $\begin{array}{l}\text { Denticles in Hypostomal row } \\
\qquad 2^{*}\end{array}$ & 7 & $6-7$ & $7-10$ & $7-8$ & $6-9$ \\
\hline $\begin{array}{l}\text { Denticles in Hypostomal row } \\
3^{*}\end{array}$ & $1-3$ & $1-2$ & $2-5$ & $1-3$ & $1-5$ \\
\hline Tarsus I: length* & $0.291 \pm 0.010(0.271-0.307)$ & $0.311 \pm 0.007(0.297-0.319)$ & $0.248-0.290$ & $0.312 \pm 0.008(0.304-0.323)$ & $0.300-0.310$ \\
\hline Tarsus I: width* & $0.086 \pm 0.007(0.077-0.102)$ & $0.089 \pm 0.005(0.082-0.096)$ & - & $0.080 \pm 0.002(0.007-0.083)$ & - \\
\hline
\end{tabular}

${ }^{\text {a }}$ Length measured to $\mathrm{Ph} 1$ insertion.

b Length measured to the insertion of hypostome.

c Length measured to Ph1 insertion.

d Length measured to point of inferior toothed portion. 

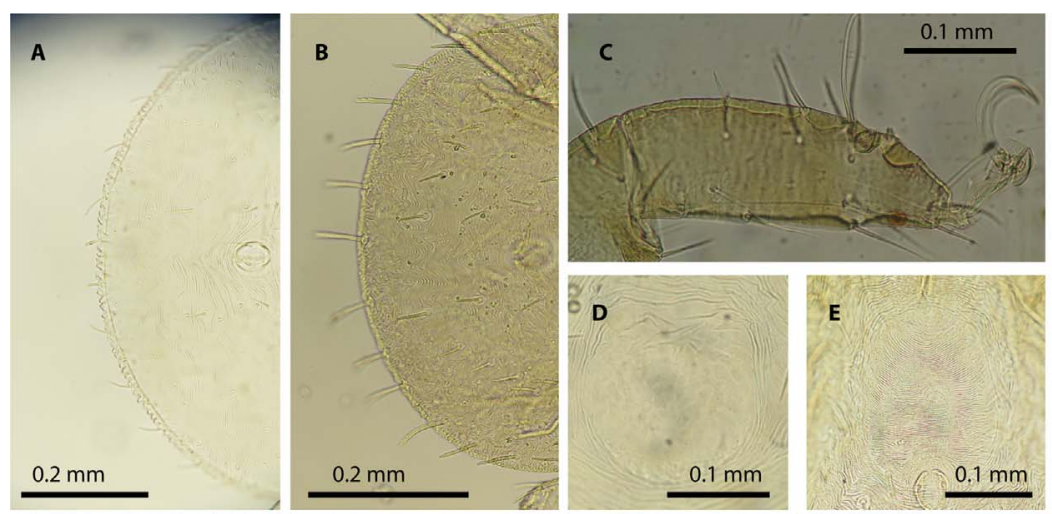

Fig. 2. Light and scanning electron microscopy micrographs of Argas (Persicargas) miniatus and Argas (Persicargas) persicus. Argas (P.) persicus: larva: (A) posterior portion of ventral idiosoma, and (D) dorsal plate; adult: (F) lateral integumental cells. Argas (P.) miniatus: larva: (B) posterior portion of ventral idiosoma, (C) tarsus I, and (E) dorsal plate; adult: (G) lateral integumental cells, $(\mathrm{H})$ ventral basis capitulum, (I) ventral capitulum, $(\mathrm{J})$ ventral view and $(\mathrm{K})$ dorsal view. Abbreviations: $\mathrm{V}$, ventral setae; Pp, postpalpal seta.
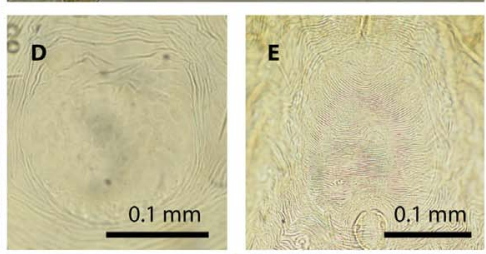
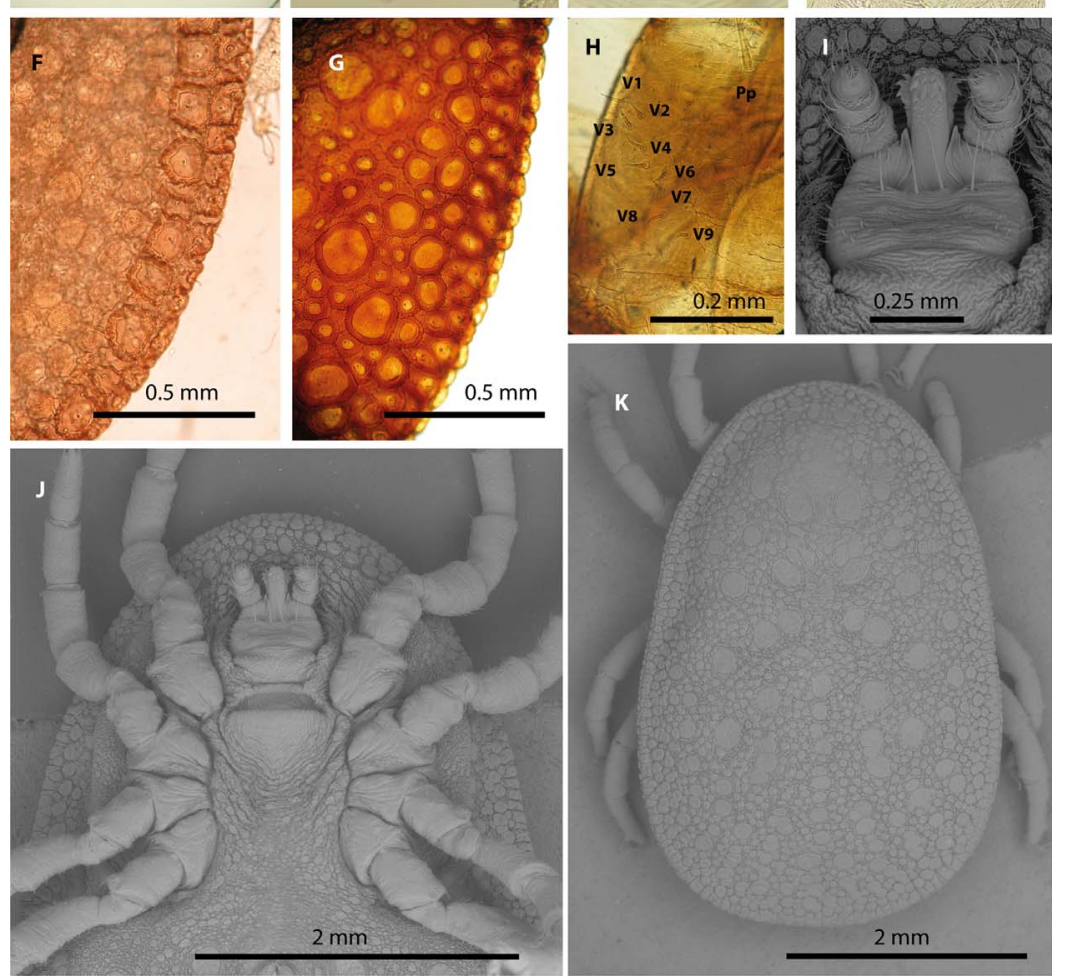

of Argas (Persicargas) were recognized. Chilean specimens were diagnosed as $A$. (P.) persicus (Oken, 1818) by the following combination of characters: Larva - dorsal plate subcircular, dorsal setae short, 14-16 dorsolateral setal pairs, nearly equal in length $(\approx 0.039 \mathrm{~mm})$; tarsus I setal formula: 1 apical pair, 3 paracapsular setae, 2 posteromedian, 1 basal, 1 apicoventral, 1 midventral, 1 posterolateral, and 2 basoventral pairs; Haller's organ without coralline reticulations and lacking a trumpet like sensillum (Kohls et al., 1970) (Fig. 2A, D). Female - a row with less than 100 large rectangular or subrectangular peripheral cells, adjacent one to another or separated either by a narrow deep groove or by a small irregular ridge; each cell provided with a large stout seta (Kohls et al., 1970) (Fig. 2F); measurements of five analyzed females were as follow (this study/Kohls et al., 1970): 6.231-8.447 (7.289 \pm 1.042)/5.10-9.75 mm length, and 3.741-5.019 $(4.434 \pm 0.552) / 3.40-6.15 \mathrm{~mm}$ width.

Argas (P.) miniatus was identified from field-collected material in Brazil, and also in CNC, CZACC and IBSP allotments by the following combination of characters: Larva - dorsal plate oval, dorsum provided with 14 dorsolateral setal pairs, 11-17 central setal pairs; tarsus I setal formula: 1 apical pair, 3 paracapsular setae, 1 pair posteromedian, 1 basal, 1 apicoventral, 1 midventral, 1 posterolateral, and 2 basoventral pairs; Haller's organ without coralline reticulations and lacking a trumpet like sensillum (Kohls et al., 1970) (Fig. 2B, C, E). Female - a row with more than 150 medium sized subrectangular, subtriangular and subcircular peripheral cells, adjacent to one another, each cell provided with one or two setal pits; basis capituli provided with 9-12 pairs of ventral setae (Kohls et al., 1970) (Fig. 2G-J); measurements of five females were as follow (CNC/Kohls et al., 1970): 5.137-6.448 $(5.703 \pm 0.586) / 4.300-7.700 \mathrm{~mm}$ length and $3.256-4.064$ $(3.610 \pm 0.344) / 2.770-4.920 \mathrm{~mm}$ width.

A comparison of larval morphometry obtained in this study with data from literature is presented in Table 1.

Vouchers in ethanol and slide-mounted specimens were deposited in the "Coleção Nacional de Carrapatos Danilo Saraiva" (CNC) at the Veterinary Medicine and Zoothecnics Faculty in University of São Paulo, São Paulo, Brazil under the following accession numbers: CNC$878,-1153,-1154,-3376,-3382,-3409$ for $A$. (P.) miniatus, and CNC-3299, -3302 for $A$. (P.) persicus.

\section{2. $P C A$}

Morphological comparison through the PCA showed a clear 


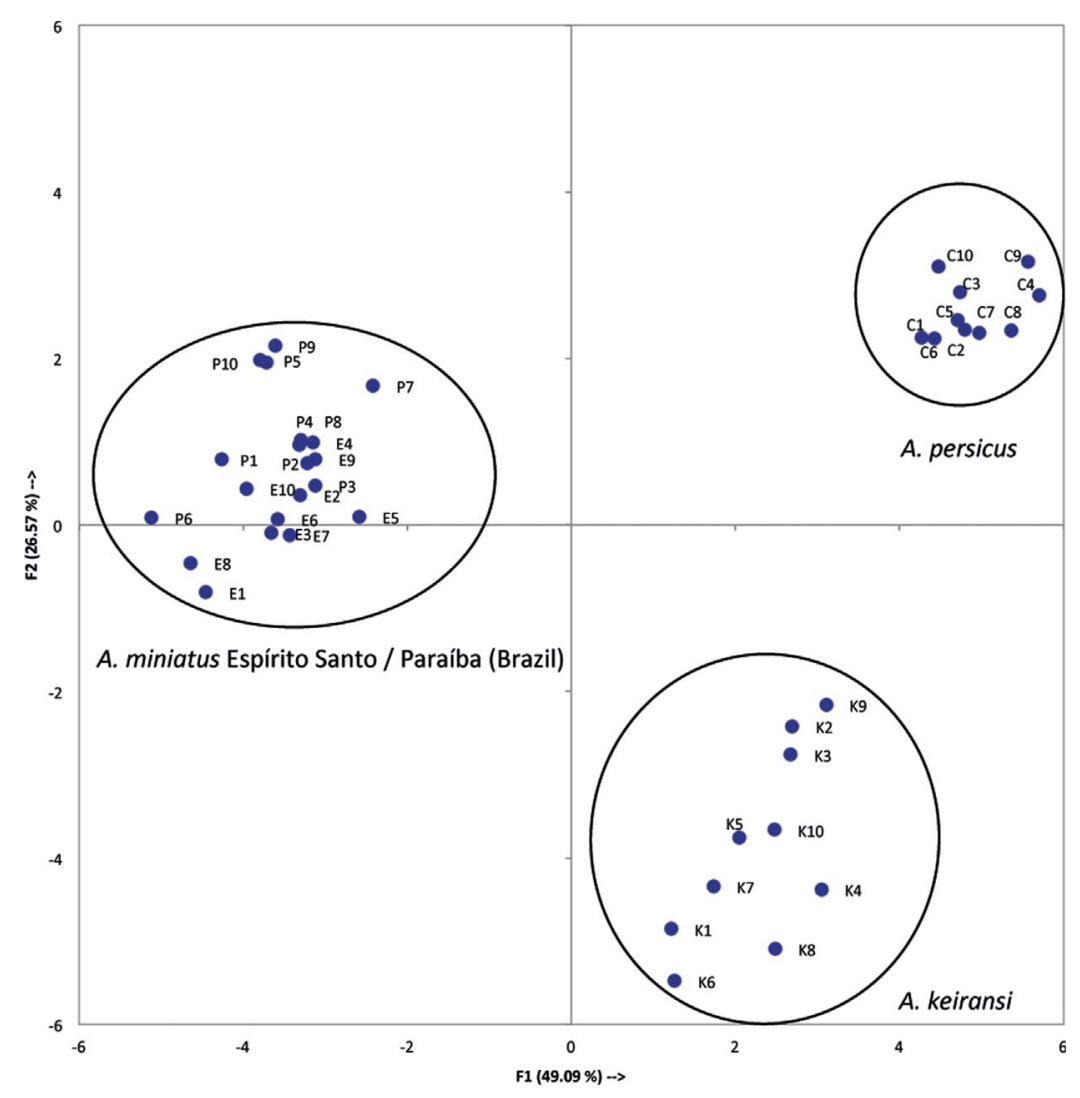

Fig. 3. Principal components analysis of $A$. (P.) miniatus from Espírito Santo state (E 1-10) and Paraíba state (P 1-10); A. (P.) persicus from Calama (C 1-10), and A. (P.) keiransi (K 1-10), using 40 morphological characters detailed in Table 1 . Each point constitutes the position of each measured specimen on the reduced space. difference between both Argas species diagnosed in the current study and also with $A$. (P.) keiransi (Fig. 3). The first principal component, which in this case explains $49.09 \%$ of the total variance, was almost fully loaded with the following characters: body length (not including capitulum), body width, hypostome length (measured to ph1), hypostome width and palpal length (articles III and IV). On the other hand, the second component explained $26.57 \%$ of the total variance, and heavier characters were represented by length of dorsal plate, dorsal setae (total pairs), central setae and tarsus I width.

\subsection{Molecular tools}

Eight ticks from Chile submitted to DNA extraction yielded identical sequences among each other and the consensus of 407-bp was deposited in GenBank under the accession number KX258880. Thirteen ticks from Brazil yielded two haplotypes of 400-bp differing in one nucleotide. One haplotype was obtained from ticks collected in Santa Teresinha (Paraiba), São Roque de Minas (Minas Gerais) and Santa Cruz do Ibitinema (Rio de Janeiro), and a second haplotype was retrieved from ticks collected in Paraiba do Sul (Rio de Janeiro) and São Mateus (Espírito Santo). Ticks from Brasília (Federal District) yielded both haplotypes. Our attempts to amplify tick DNA in both Cuban specimens were unsuccessful. Sequences from Brazil were deposited in GenBank under the accession numbers KX855206 - KX855210, KY705380 and KY705381. By BLAST analyses we confirmed our morphological diagnoses, since partial mitochondrial 16S rDNA sequences obtained from Chilean ticks were $100 \%$ (407-bp) identical to $A$. (P.) persicus from Italy (GU451248), and the Brazilian ticks yielded sequences 99\% (399/400bp) $-100 \%$ identical to A. (P.) miniatus (KC769590).

\subsection{Phylogenetic analysis}

The phylogenetic tree clearly shows representatives of Argas (Persicargas) grouping in a separated clade supported by high bootstrap.
Within this branch, A. (P.) miniatus formed a clade with Argas (Persicargas) walkerae Kaiser \& Hoogstraal, 1969, and A. (P.) keiransi appeared as a sister taxon of $A$. (P.) persicus (Fig. 4).

\subsection{Literature revision and mapping}

Both Argas species have been reported in 145 American localities. Argas (P.) persicus has documented collections in 45 localities from North America, and in 25 from South America. In turn, documented distribution of $A$. (P.) miniatus includes 65 localities in South America, and 10 reports from North America (Table 2). Overall, 69\% (101/145) of the reports lack a reliable morphological or molecular analysis for the species diagnosis. Confirmed reports for both soft tick species fall within arid, equatorial, and warm temperate climate regimes, however records of $A$. (P.) persicus also reach desert ecosystems (Fig. 5).

\section{Discussion}

Species diagnosis of immature and mature Argas (Persicargas) ticks constitutes a challenging task (Khalil et al., 1980). Setal distribution and dimensions in the dorsal and ventral faces of larvae are often similar and, in these cases, differences of micrometers are assumed to separate the species (Sonenshine, 1962; Hoogstraal et al., 1968; Kohls et al., 1970). In adults, important differences are described upon the fine anatomy of the dorsal integument, including the form and disposition of peripheral cells (Kohls et al., 1970). Therefore, taking into account morphological similarities within species of Argas (Persicargas) group, a molecular characterization is suitable to confirm previous diagnoses.

\subsection{Morphological study}

Larval and adult morphology of Argas sp. collected in Brazil was concordant with the redescription of $A$. (P.) miniatus. Although a 


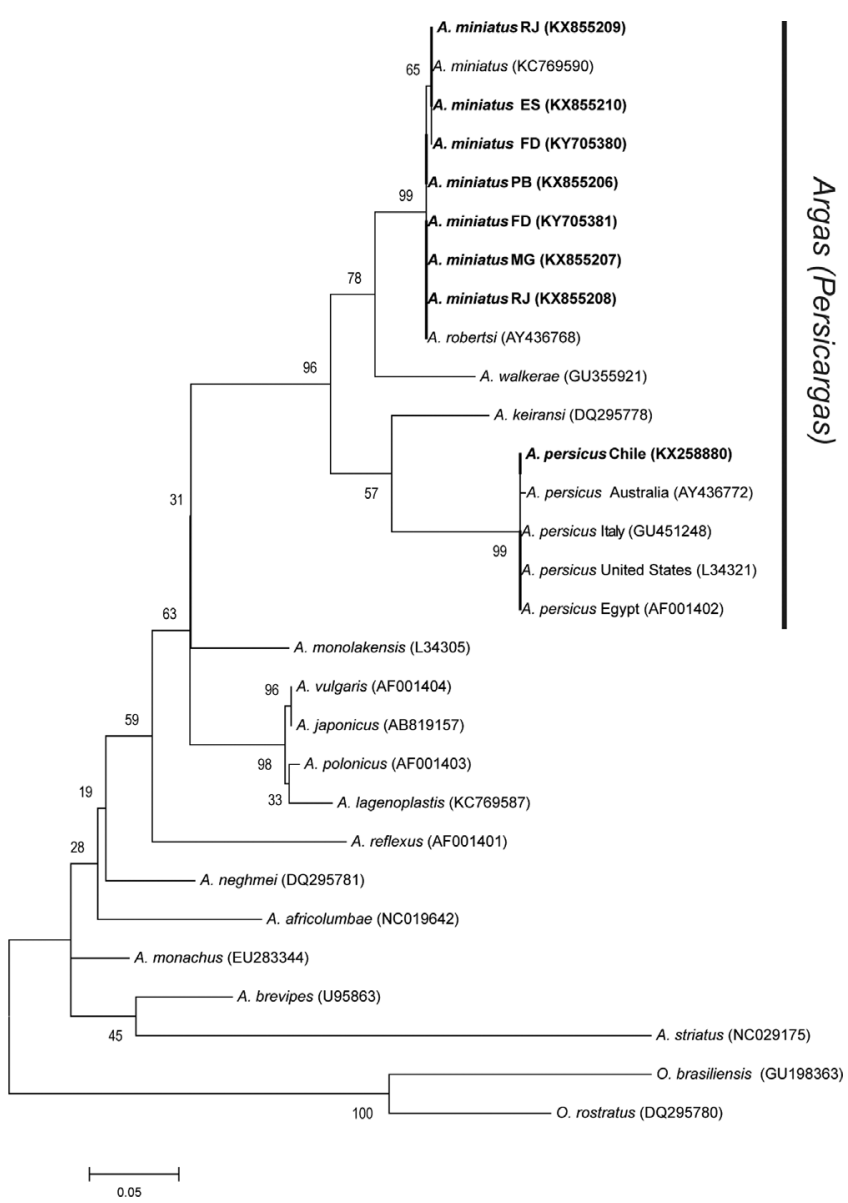

Fig. 4. Phylogenetic tree of Argas spp. The sequences obtained in the current study are highlighted in bold. Abbreviations: A., Argas; O., Ornithodoros; ES, Espírito Santo state; FD, Federal District; MG, Minas Gerais state; PB, Paraiba state, RJ: Rio de Janeiro state.

specific diagnosis by molecular tools was not possible, probably by an advanced state of DNA degradation, the morphological identification of adults $A$. (P.) miniatus from Cuba was supported by the combination of 9-12 ventral pairs of setae in the capitulum, the anatomy of the dorsal tegument, and the presence of more than 150 peripheral cells (Fig. 2I, $\mathrm{K})$. These morphological differences also separate examined Cuban Argas from $A$. (P.) radiatus and $A$. (P.) sanchezi, since both later species present more than 16 pairs of ventral setae in the capitulum (Kohls et al., 1970).

All the measured characters of $A$. (P.) persicus larvae obtained from Chilean specimens are concordant with the dimensions given in the species redescription, with the exception of dorsal plate, which was smaller in our specimens $(0.163 \mathrm{~mm}$ length-0.171 $\mathrm{mm}$ width). Differences in the dimensions of this character were also noticed by Kohls et al. (1970), since larvae from the United States (Pennsylvania) had a smaller dorsal plate when comparing with larval specimens from other origin. Considering this variability, it seems that the dorsal plate could be a polymorphic character uninformative when performing specific morphological diagnoses, at least for this species.

When comparing measurements of Argas (Persicargas) obtained by our methodology (Fig. 1) by means of a PCA analysis, heavier characters that separate species are represented by the size of the body, hypostome width and length of articles III and IV. This suggests that these traits possess enough interspecific variability, and could correspond to a valuable set for performing morphological comparisons with the rest of Argas (Persicargas) species in order to discriminate between taxa.

In the current study, the nomenclature of characters proposed by Sonenshine et al. (1962) was considered for analyzing slide-mounted larvae. These authors stated that only for Chiropterargas subgenus dorsolateral setae were arranged in anterior (DAL setae) and posterior groups (DPL setae), and that for the rest of subgenera, no evident separation of these traits was observed. Conversely, while posterior descriptions of Argas species did include averages of DAL and DPL setae, a clear anatomical definition noting the number of setae for each group was not specified. This fact is evidenced in the descriptions of $A$. (P.) miniatus and A. (P.) persicus larval stages (Kohls et al., 1970), and prompted the exclusion of these characters in our morphological analyses.

\subsection{Molecular analyses}

While the mitochondrial 16S rDNA sequences of Brazilian A. (P.) miniatus characterized in this study confirmed the identity of the species, it was also evidenced that Argas (Persicargas) robertsi Hoogstraal, Kaiser \& Kohls, 1968 from Australia has a mitochondrial 16S rDNA sequence $99-100 \%$ similar to $A$. ( $P$.) miniatus from Brazil. This intriguing coincidence between two Argas (Persicargas) species with vastly distanced geographical distributions was already pointed by Burger et al. (2014). These authors noted that either $A$. (P.) robertsi was present in America, being A. (P.) miniatus a local race of the Australian tick, or the GenBank number of $A$. (P.) robertsi (AY436768) was misidentified. Although we do not discard the second possibility, to assume that both Argas correspond rather to one geographically widespread species needs further foundation. Still, it is noteworthy to mention that morphological traits of larvae and adults stages of both soft ticks are extremely similar, a fact that complicates even more the scenario. While genetic and morphological similarity in both species constitutes a problematic question yet to be solved, a detailed morphological study, the characterization of less conserved genes and an assessment of reproductive isolation mechanisms would constitute useful approaches in order to decide their validity as taxa.

Obtained mitochondrial 16S rDNA sequence of the Chilean A. (P.) persicus was identical to conspecific sequences characterized from Italian specimens (Pantaleoni et al., 2010), and 99\% identical with $A$. (P.) persicus from Australia and the United States. As this tick species is a common parasite of poultry (Kohls et al., 1970; Hoogstraal, 1985; Petney et al., 2004), it is reasonable to say that its entrance to Chile could have been via infested chickens. Argas (P.) persicus is an originally Palaearctic species spread to many parts of the world (Hoogstraal, 1985, 1956), and constitutes a recognized poultry parasite of medical importance. It has been documented as a vector of Borrelia anserina and Aegyptianella pullorum, implicated in the circulation of West Nile virus and also in persistent infections of Salmonella gallinarum and Salmonella pullorum (Stefanov et al., 1975; Hoogstraal, 1985). Moreover, Rickettsia spp. of the Spotted Fever and Transitional groups have been reported in A. (P.) persicus from Europe (Rehácek et al., 1977) and Africa (Pader et al., 2012), respectively. However, the vector competence of this tick in relation with these microorganisms must still be assessed.

\subsection{Geographical distribution in America}

Argas (Persicargas) ticks associated with domestic chicken have been widely reported in America. Documented records of $A$. (P.) miniatus and $A$. (P.) persicus were published in taxonomical works (Nuttall et al., 1908; Cooley and Kohls, 1944; Kohls et al., 1970), list of species or reports for a specific region (Hooker, 1909; Rohr, 1909; Lahille, 1915; Dunn, 1923; Vogelsang, 1928; Vigueras, 1934; Aragão, 1935, 1936, 1938; Hearle, 1938; Osorno-Mesa, 1940; Vogelsang and Cordero, 1940; Bishopp and Trembley, 1945; Boero, 1945; Hoffmann, 1962; Fairchild et al., 1966; De La Cruz, 1974, 1976; Capriles and Gaud, 1977; Keirans, 1984; Need et al., 1991; Ivancovich and Luciani, 1992; Evans et al., 2000; Nava et al., 2004; Guglielmone and Nava, 2005; Acosta et al., 2016; Castillo-Martínez et al., 2016), biological studies (Lorosa et al., 2007; Santos et al., 2010), and research related to Borrelia anserina 


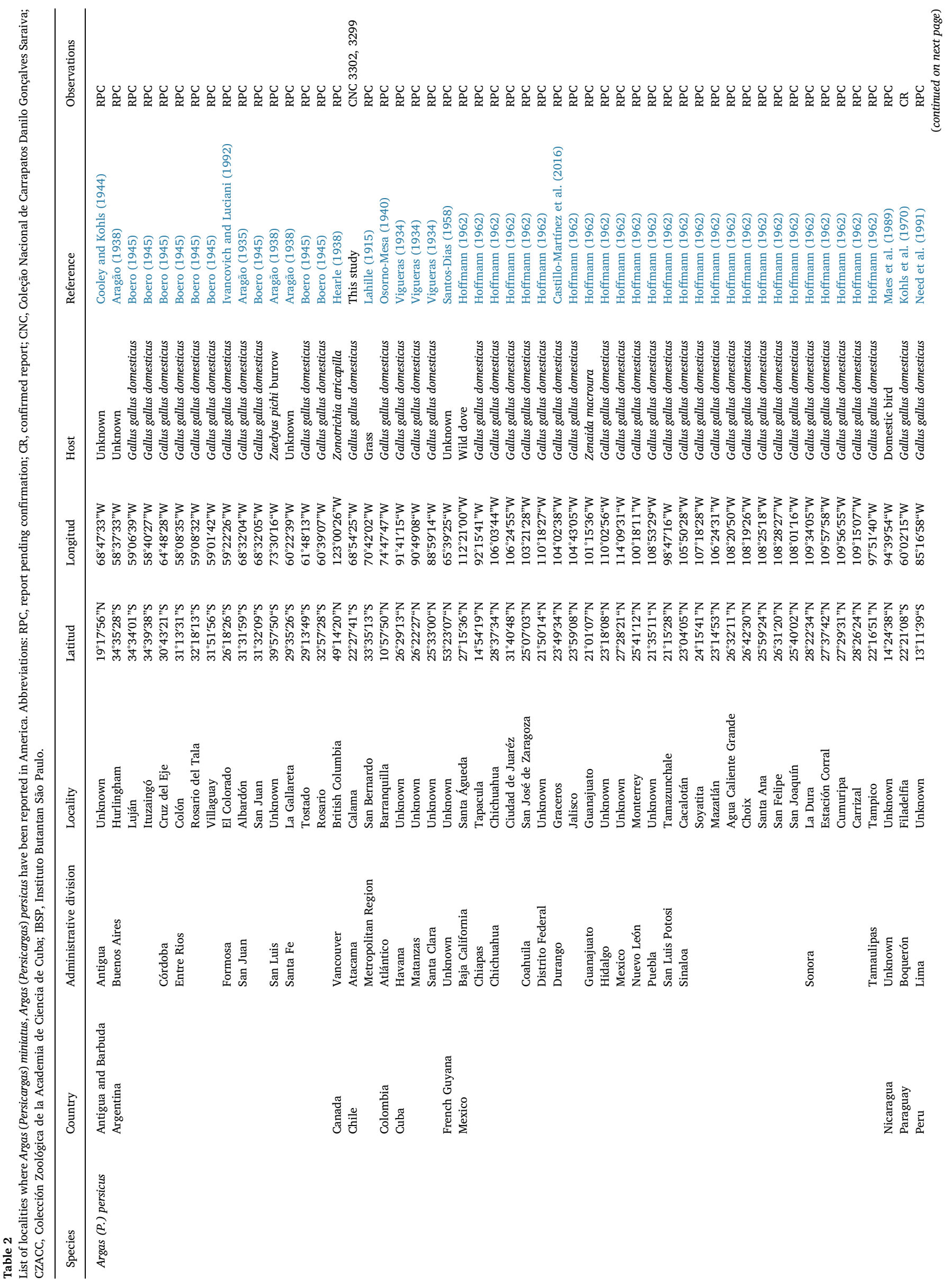




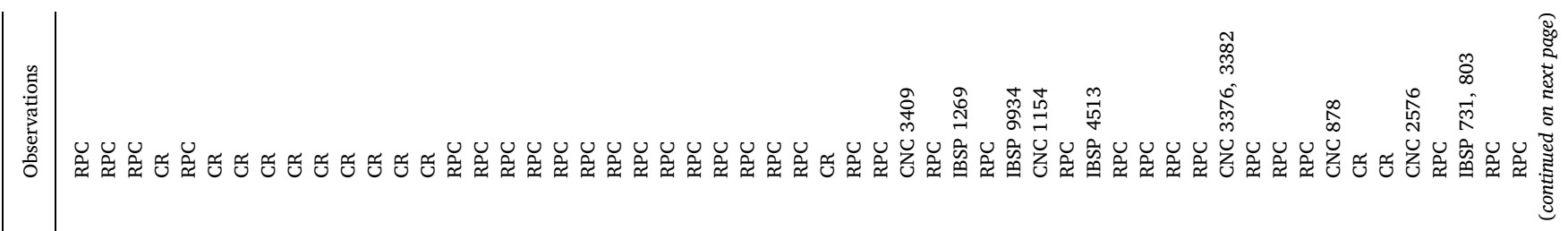

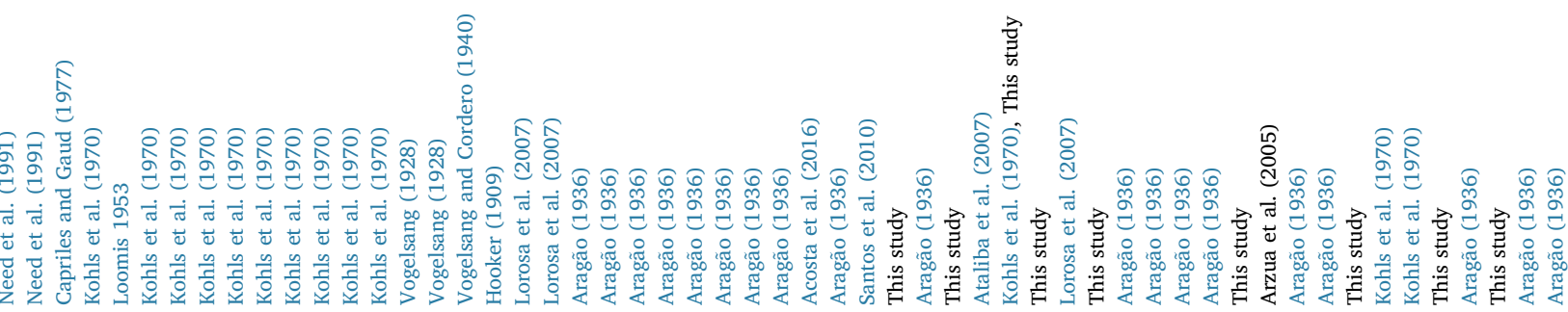

प

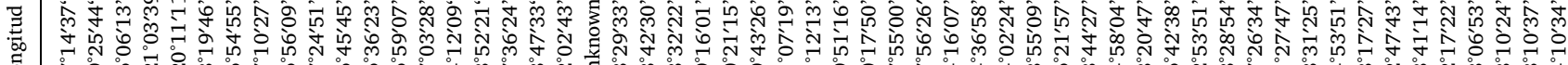

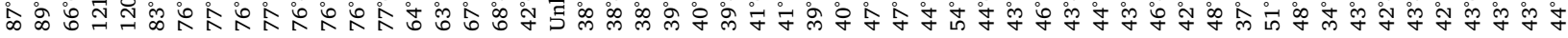

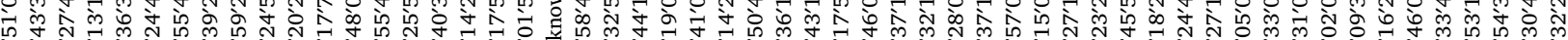

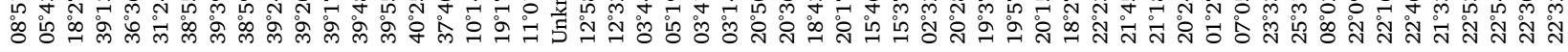

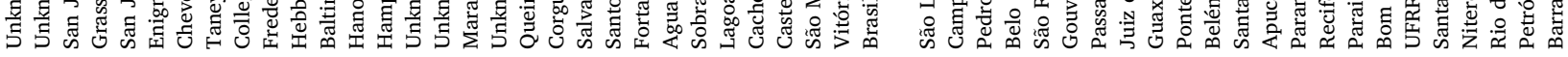<smiles>CC1[C@H](C)C[C@H]1C</smiles> 


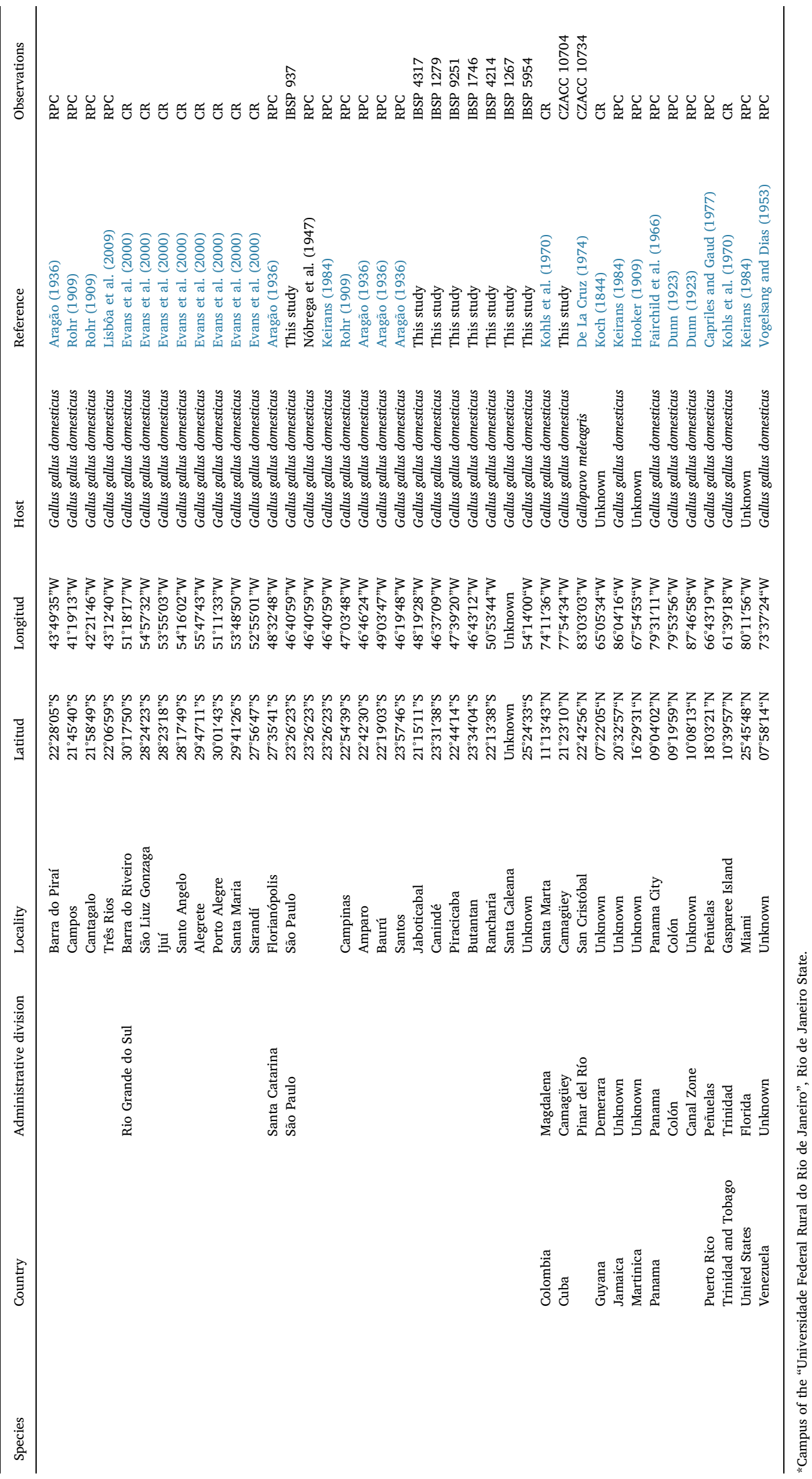




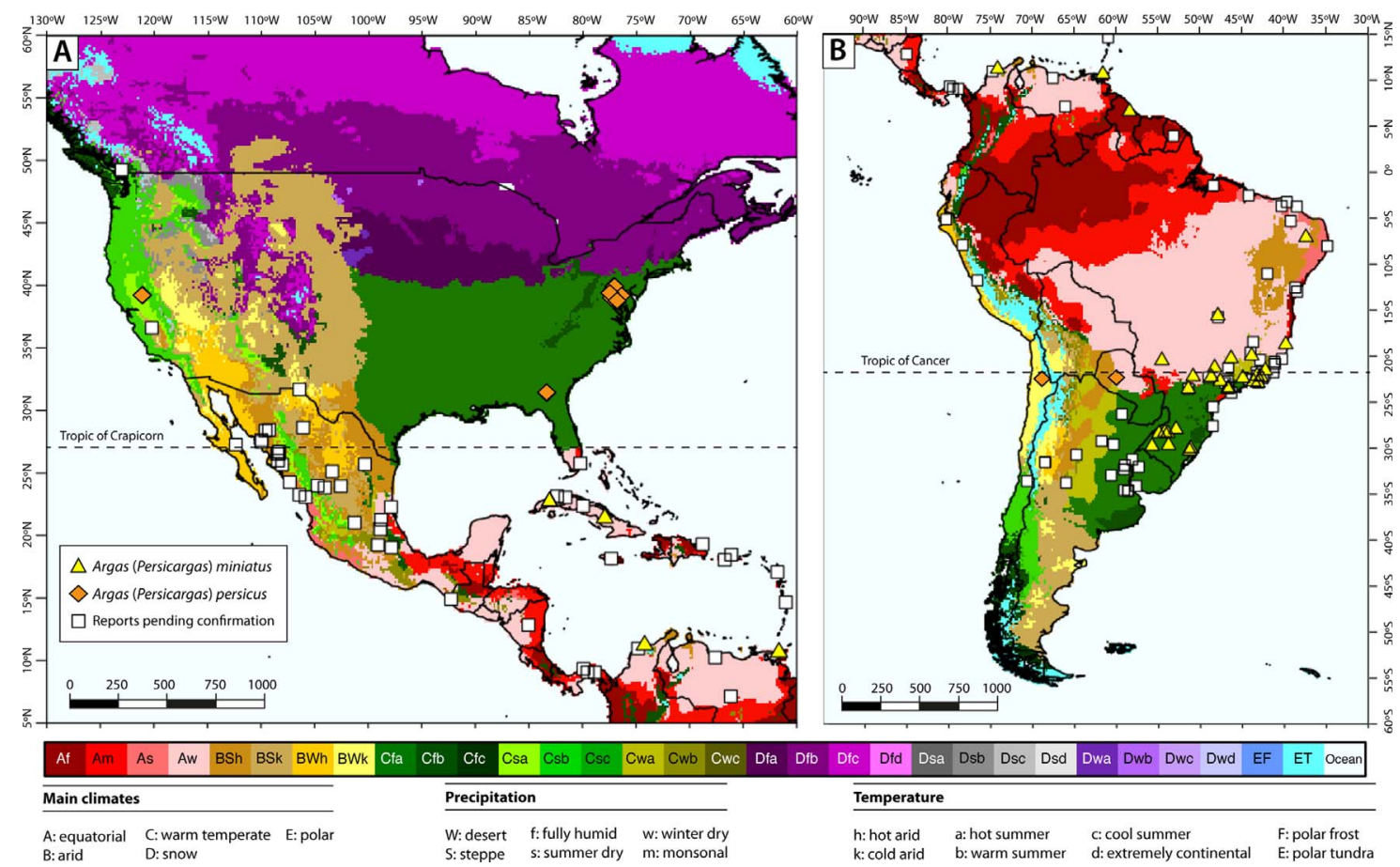

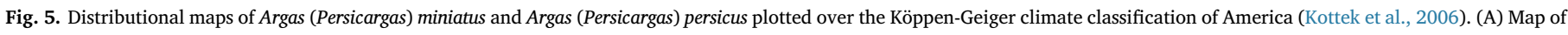
North and Central America. (B) Map of South America.

(Marchoux and Salimbeni, 1903; Nóbrega and Reis, 1947; Loomis, 1953; Ataliba et al., 2007; Lisbôa et al., 2009), which is transmitted by these group of ticks. However, early reports of both species for America are unclear and it is difficult to assign an identity without a reexamination of the collected material. For this reason the majority of the records for $A$. (P.) miniatus and $A$. (P.) persicus should be considered as provisory or pending confirmation.

\subsubsection{North America}

In Canada, four nymphs of $A$. (P.) miniatus were identified by Hearle (1938) from specimens collected in a golden-crowned sparrow (Zonotrichia atricapilla) at Vancouver. Cooley and Kohls (1944) and Gregson (1956) subsequently referred to this record as $A$. (P.) persicus, which to date, corresponds to the sole report of this species for this country and to the northernmost record for America.

In the United States, reports of $A$. (P.) persicus from Arizona, Florida, Iowa, Nevada, New Mexico, Texas and Utah states, summarized by Bishopp (1941) and Cooley and Kohls (1944), were subsequently identified either as $A$. $(P$.) radiatus or $A$. $(P$.) sanchezi by Kohls et al. (1970). These same authors posed the possibility that $A$. (P.) miniatus could have been introduced into the United States; however the inadequate state of the material available for examination precluded an accurate species determination (Kohls et al., 1970). On the other hand, Hoogstraal (1985) still assumed that this species does occur in "small foci" in southeastern regions of the United States.

Hoffmann (1962) listed the distribution of A. (P.) persicus for Mexico, naming several states along the country. Remarkably, some of the reports had a common distribution with the geographical range of $A$. (P.) radiatus and A. (P.) sanchezi (Baja California, Durango, Guanajuato, and Tamaulipas) proposed by Kohls et al. (1970). Moreover, according to Hoffmann (1962), A. (P.) persicus has been collected from the morning dove Zenaida macroura (L. 1758), which constitutes the type host of $A$. (P.) sanchezi (Kohls et al., 1970). While it is highly possible that $A$. $(P$.) persicus occurs in Mexico, historical confusion with other Argas species precludes an accurate distribution for this country (Hoffmann and López-Campos, 2000).

\subsubsection{Central America and Caribe}

Panamanian reports of $A$. (P.) persicus (Fairchild et al., 1966) were subsequently questioned by Kohls et al. (1970), noting that these specimens could have been misidentified, and rather correspond to $A$. (P.) miniatus. In fact Kohls et al. (1970) included immature and mature specimens of unknown host and locality collected in Panama when they redescribed $A$. (P.) miniatus. Early reports of Dunn (1923) already included this tick as parasites of domestic chicken in this country, which supports the presence of $A$. (P.) miniatus and not $A$. (P.) persicus in Panama.

The first report of $A$. (P.) miniatus in Cuba was presented by Hooker (1909) in a review of the geographical distribution of ticks from America. Since then, the presence of this tick was not questioned for the island. However, Kohls et al. (1970) excluded Cuba within its distribution, presumably because they did not examine any available material (De La Cruz, 1976). On the other hand, after the examination of soft ticks collected in a poultry farm from Camagüey (CZACC 10704), De La Cruz (1976) stated that $A$. (P.) persicus was also established in Cuba. In the current study, we were able to morphologically examine one male and three nymphs of this original allotment, and found that these ticks corresponded to $A$. (P.) miniatus. Moreover, we confirmed the presence of this tick in Cuba by the examination of an additional Argas allotment from San Cristóbal (CZACC 10734).

In other Caribbean islands where both species of soft tick have been reported (Antigua and Puerto Rico), new assessments must be undertaken, either by the collection of new material, or by the reexamination of deposited specimens in order to clarify the identity of these ticks. In the same way, records of $A$. (P.) persicus from Nicaragua documented by Maes et al. (1989) should be considered as doubtful.

\subsubsection{South America}

The first report of $A$. (P.) miniatus for Brazil was made in 1903 by Marchoux and Salimbeni (1903), as part of research with $B$. anserina. Subsequent literature referred to this tick as a synonym of $A$. (P.) persicus in America (Nuttall et al., 1908), and particularly in Brazil, A. (P.) miniatus was considered to be a morphological variety named as $A$. (P.) persicus var. dissimile (Aragão, 1936). In the present study we examined 
the totality of Brazilian allotments of Argas ticks deposited in the IBSP, and concluded that all the specimens corresponded to $A$. (P.) miniatus. With this, we confirm that this species has a wide distribution in this country. Moreover, it is highly possible that the rest of unconfirmed reports might also correspond to the same species.

While the presence of $A$. (P.) miniatus has not been confirmed for Argentina, Guglielmone and Nava (2005) considered that reports of $A$. (P.) persicus published by early and contemporary researchers (o, 1935, 1938; o, 1935, 1938; Boero, 1945; Ivancovich and Luciani, 1992) would rather correspond to $A$. (P.) miniatus. Remarkably, Nava et al. (2004) confirmed the presence of $A$. (P.) persicus in Argentina through a morphological analysis of one female of unknown host and locality. This fact still leaves as uncertain the occurrence of $A$. (P.) miniatus in this country, and raises the possibility that previous reports of $A$. (P.) persicus might be valid.

In Chile, the reports of $A$. (P.) persicus made by Lahille (1915) and Porter (1928), with material collected in Calama, were subsequently considered synonyms of $A$. (A.) neghmei by Kohls and Hoogstraal (1961). Here, combining a morphological analysis of larvae with a molecular characterization of these and other postlarval stages, we confirm the presence of $A$. ( $P$.) persicus for the first time in this country. As our collections were also from Calama, it implicates that this soft tick might occur in sympatry with A. (A.) neghmei. Since Lahille (1915) also reported an $A$. $(P$.) persicus variety from San Bernardo in the Metropolitan Region, the distribution of this tick in Chile might be underestimated.

Although Vogelsang (1928) reported the presence of $A$. (P.) persicus for Uruguay, it is probable that $A$. (P.) miniatus also occurs in this country (Venzal et al., 2003). In the same way, while $A$. (P.) persicus occurs in Paraguay (Kohls et al., 1970) the presence of $A$. (P.) miniatus should not be discarded (Nava et al., 2007).

\subsection{Distribution according to Köppen-Geiger climate classification}

When contrasted to the Köppen-Geiger climate classification of America, confirmed reports for $A$. (P.) miniatus are almost exclusively distributed within an equatorial climate regime well delimited by both tropic lines. Conversely, the distribution of $A$. (P.) persicus excludes equatorial climates, and rather overlaps with arid climates, which in particular, correspond to an ecologically constant trait among its world distribution (Hoogstraal, 1956, 1985; Petney et al., 2004). Apart of this apparently dual distribution according to equatorial and arid climate regimes, both ticks share distributional ranges within warm temperate climates: A. (P.) miniatus in South America, and A. (P.) persicus in North America. On the other hand, more than a half (69\%) of the reports are yet to be confirmed, and they are located in all three above stated climates. Considering this distributional scenario, unless reports pending confirmation are properly determined, any major conclusion on the distribution of both soft ticks in accordance to climates of the American continent will be rather speculative.

\section{Conflict of interest}

The authors declare no financial or personal conflicts of interest that could bias the study.

\section{Acknowledgments}

We are grateful to René Muñoz Klock for providing the transport for the field expedition to northern Chile in 2014. To Cecilia Figueroa and Nicolás Fernández for their valuable help in fieldwork. To Herminio Urra and Maritza Cabrera from Calama (Chile) and Fernando Corassa from Brasília (Brazil), for kindly allowed us to examine hen houses within their properties. To Luis Gonzalo Torres for is assistance with the laboratory work. To Isabella Fontana and Gina Polo for their valuable assistance in the confection of maps. To the Departamento de
Cooleciones Zoológicas del Instituto de Ecología y Sistemática (La Habana, Cuba), and to Valeria Onofrio from the Coleção Acarológica do Instituto Butantan (São Paulo, Brazil), for gently lend us material for examination. MR was funded by CAPES grant \#14699626631. DGA was funded by FONDECYT project \#1170972. SML was funded by CONICYT Programa de Formación de Capital Humano Avanzado, grant \#72140079.

\section{References}

Acosta, I.C.L., Martins, T.F., Marcili, A., Soares, H.S., Krawczak, F.S., Vieira, F.T., Labruna, M.B., 2016. Ticks (Acari: Ixodidae, Argasidae) from humans, domestic and wild animals in the state of Espírito Santo, Brazil, with notes on rickettsial infection. Vet. Parasitol. Reg. Stud. Rep. 3-4, 66-69. http://dx.doi.org/10.1016/j.vprsr.2016. 08.001 .

Aragão, H. de B., 1935. Observações sobre os Ixodideos da Republica Argentina. Mem. Inst. Oswaldo Cruz 30, 519-533. http://dx.doi.org/10.1590/S007402761935000900011.

Aragão, H. de B., 1936. Ixodidas Brasileiros e de alguns paizes limitrophes. Mem. Inst. Oswaldo Cruz 31, 759-843.

Aragão, H. de B., 1938. Nota sobre los ixodoideos de la república de Argentina. Mem. Inst. Oswaldo Cruz 33, 319-327.

Ataliba, A.C., Resende, J.S., Yoshinari, N., Labruna, M.B., 2007. Isolation and molecular characterization of a Brazilian strain of Borrelia anserina, the agent of fowl spirochaetosis. Res. Vet. Sci. 83, 145-149. http://dx.doi.org/10.1016/j.rvsc.2006.11. 014.

Bishopp, F.C., Trembley, H.L., 1945. Distribution and hosts of certain North American ticks. J. Parasitol. 31, 1-54.

Bishopp, F.C., 1941. The Fowl Tick and How Premises May Be Freed from It. U.S. Dept. of Agriculture, Washington.

Boero, J.J., 1945. Los ixodideos de la República Argentina. Rev. Med. Vet. (Bogota) 1-2.

Burger, T.D., Shao, R., Labruna, M.B., Barker, S.C., 2014. Molecular phylogeny of soft ticks (Ixodida: Argasidae) inferred from mitochondrial genome and nuclear rRNA sequences. Ticks Tick Borne Dis. 5, 195-207. http://dx.doi.org/10.1016/j.ttbdis. 2013.10.009.

Burroughs, A.L., 1947. Fowl spirochetosis transmitted by Argas persicas (Oken), 1818 from Texas. Science 105, 577.

Capriles, J.M., Gaud, S.M., 1977. The ticks in Puerto Rico. J. Agric. Univ. Puerto Rico 61, 402-404.

Castillo-Martínez, A., Cueto-Medina, S., Méndez-López, R., Pérez-Muñoz, R., HernándezRodríguez, S., Ortega-Morales, A., 2016. Garrapatas (Acari Ixodidae, Argasidae) de la comarca Lagunera en Durango. México Entomol. Mex. 3, 26-32.

Chen, Z., Yang, X., Bu, F., Yang, X., Yang, X., Liu, J., 2010. Ticks (Acari: Ixodoidea: Argasidae, Ixodidae) of China. Exp. Appl. Acarol. 51, 393-404. http://dx.doi.org/10. 1007/s10493-010-9335-2.

Cooley, R.A., Kohls, G.M., 1944. The Argasidae of North America, Central America and Cuba. Am. Midl. Nat Monograph No. 1.

Corwin, D., Clifford, C.M., Keirans, J.E., 1979. An improved method for cleaning and preparing ticks for examination with the scanning electron microscope. J. Med. Entomol. 16, 352-353.

Cumming, G.S., 1999. Host distributions do not limit the species ranges of most African ticks (Acari: Ixodida). Bull. Entomol. Res. 89, 303-327. http://dx.doi.org/10.1017/ S0007485399000450.

DIVA-GIS, 2011. Global Country Boundaries Shapefile.

De La Cruz, J., 1974. Notas adicionales a la fauna de garrapatas (Ixodoidea) de Cuba I. Argasidae de las aves. Poeyana 129, 1-3.

De La Cruz, J., 1976. Notas adicionales a la fauna de garrapatas (Ixodoidea) de Cuba. IV. Presencia de Argas (Persicargas) persicus (Oken, 1818). Misc. Zool. 2, 1-3.

Dunn, H., 1923. The ticks of panama, their hosts, and the diseases they transmit. Am. J. Trop. Med. Hyg. s1-3, 91-104.

Estrada-Peña, A., Venzal, J.M., González-Acuña, D., Guglielmone, A.A., 2003. Argas (Persicargas) keiransi n. sp. (Acari: Argasidae), a parasite of the Chimango, Milvago $c$ chimango (Aves: Falconiformes) in Chile. J. Med. Entomol. 40, 766-769. http://dx. doi.org/10.1603/0022-2585-40.6.766.

Evans, D., Martins, J., Guglielmone, A., 2000. A review of the ticks (Acari, Ixodida) of Brazil, their hosts and geographic distribution - 1. The state of Rio Grande do Sul, southern Brazil. Mem. Inst. Oswaldo Cruz 95, 453-470. http://dx.doi.org/10.1590/ S0074-02762000000400003.

Fairchild, G.B., Kohls, G.M., Tipton, V.J., 1966. The ticks of Panama. Fieldiana Zool. $167-219$.

Gregson, J.D., 1956. The Ixodoidea of Canada. Canada Department of Agriculture, Ottawa, Ontario.

Guglielmone, A.A., Nava, S., 2005. Las garrapatas e la familia Argasidae y de los géneros Dermacentor, Haemaphysalis, Ixodes y Rhipicephalus (Ixodidae) de la Argentina. Distribución y Hospedadores Ria 34, 123-141.

Guglielmone, A., a Robbins, R.G., Apanaskevich, D., Petney, T.N., Estrada-Peña, A. Horak, I.G., Shao, R., Barker, S.C., 2010. The Argasidae, Ixodidae and Nuttalliellidae (Acari: Ixodida): a world list of valid tick names. Zootaxa 2528, 1-18.

Hall, T., 1999. BioEdit: a user-friendly biological sequence alignment editor and analysis program for Windows 95/98/NT. Nucleic Acids Symp. Ser. 41, 95-98 citeulike-article-id:691774.

Hearle, E., 1938. Ticks of British Columbia. Sci. Agric. 18, 341-354.

Hoffmann, A., López-Campos, G., 2000. Biodiversidad de los ácaros en México. 
Fideicomis, Mexico.

Hoffmann, A., 1962. Monografía de los Ixodoidea de México. Parte I. Rev. Soc. Mex. Hist. Nat. 23, 191-307.

Hoogstraal, H., Kaiser, M.N., Kohls, G.M., 1968. The subgenus Persicargas (Ixodoidea, Argasidae, Argas). 4. Argas (P.) robertsi, new species, a parasite of australian fowl, and keys to australian argasid species. Ann. Entomol. Soc. Am. 61, 535-539.

Hoogstraal, H., 1956. African Ixodoidea. Volume I ticks of the Sudan. U.S. Nav. Med. Res. I, 1101. http://dx.doi.org/10.5962/bhl.title.6870.

Hoogstraal, H., 1985. Argasid and nuttalliellid ticks as parasites and vectors. Adv. Parasitol. 24, 135-238. http://dx.doi.org/10.1016/j.geomorph.2005.06.008.

Hooker, W.A., 1909. The geographical dsitribution of American ticks. J. Econ. Entomol. 2, 403-428.

Ivancovich, J.C., Luciani, C.A., 1992. Las garrapatas de Argentina. Monografia Asociación Argentina de Parasitología Veterinaria.

Kaiser, M.N., Hoogstraal, H., Kohls, G.M., 1964. The subgenus Persicargas, new subgenus (Ixodoidea, Argasidae, Argas). 1. A. (P.) arboreus, new species, an Egyptian persicuslike parasite of wild birds, with a redefinition of the subgenus Argas. Ann. Entomol. Soc. Am. 57, 60-69.

Kearse, M., Moir, R., Wilson, A., Stones-Havas, S., Cheung, M., Sturrock, S., Buxton, S., Cooper, A., Markowitz, S., Duran, C., Thierer, T., Ashton, B., Meintjes, P., Drummond, A., 2012. Geneious basic: an integrated and extendable desktop software platform for the organization and analysis of sequence data. Bioinformatics 28, 1647-1649. http://dx.doi.org/10.1093/bioinformatics/bts199.

Keirans, J.E., 1984. George Henry Falkiner Nuttall and the Nuttall Ticks Catalogue. U.S. Departament of Agriculture Miscellaneous Publication No 1438.

Khalil, G.M., Hoogstraal, H., Oliver, J.H., 1980. Biological evaluation of the sytematic validity of the african Argas (Persicargas) arboreus and the asian-Australian A. (P.) robertsi (Ixodoidea: Argasidae). Int. J. Parasitol. 10, 253-259.

Klompen, J.S.H., 1992. Comparative morphology of argasid larvae (Acari: Ixodida: Argasidae), with notes on phylogenetic relationships. Ann. Entomol. Soc. Am. 85, 541-560. http://dx.doi.org/10.1093/aesa/85.5.541.

Koch, C., 1844. Systematische uebersicht über die ordnung der zecken. Arch. Natur. 10, 217-239.

Kohls, G.M., Hoogstraal, H., 1961. Observations on the subgenus Argas (Ixodoidea Argasidae, Argas). 4. A. neghmei, new species, from poultry houses and human habitations in Northern Chile. Ann. Entomol. Soc. Am. 54, 844-851.

Kohls, G.M., Hoogstraal, H., Clifford, C.M., Kaiser, M.N., 1970. The subgenus persicargas (Ixodea, Argasidae, Argas). 9. Redescription and new world records of Argas (P.) persicus (Oken), and resurrection, redescription, and records of A. (P.) radiatus Railliet, A. (P.) sanchezi Duges, and A. (P.) miniatus Koch. New Ann. Entomol. Soc. Am. 63, 590-606. http://dx.doi.org/10.1093/aesa/63.2.590.

Kottek, M., Grieser, J., Beck, C., Rudolf, B., Rubel, F., 2006. World map of the KöppenGeiger climate classification updated. Meteorol. Zeitschrift 15, 259-263. http://dx. doi.org/10.1127/0941-2948/2006/0130.

Lahille, F., 1915. Nota sobre los argásidos chilenos. Ann. Zool. Apl. (Agríc. Med. Vet.) 2, $5-11$.

Lisbôa, R.S., Teixeira, R.C., Rangel, C.P., Santos, H.A., Massard, C.L., Fonseca, A.H., 2009. Avian spirochetosis in chickens following experimental transmission of Borrelia anserina by Argas (Persicargas) miniatus. Avian Dis. 53, 166-168. http://dx.doi.org/10. 1637/8377-061508-Reg.1.

Loomis, E.C., 1953. Avian spirochetosis in California turkeys. Am. J. Vet. Res. 14, 612-615.

Lorosa, E.S., Andrade, R.E., Valente, M.V.M., Faria, M.S., Cruz, J.R., Gazeta, G.S., 2007. Inespecificidade parasitária em Argas (Persicargas) miniatus Koch, 1844 (Acari: Argasidae). Arq. Bras. Med. Veterinária e Zootec. 59, 1485-1488. http://dx.doi.org/ 10.1590/S0102-09352007000600021.

Maes, J.M., Palacios-Vargas, J.G., Jimenez, M.L., 1989. Catálogo de los artrópodos terrestres no insectos de Nicaragua. Rev. Nicar. Entomol. 7, 1-55.

Mangold, A.J., Bargues, M.D., Mas-Coma, S., 1998. Mitochondrial 16S rDNA sequences and phylogenetic relationships of species of Rhipicephalus and other tick genera among Metastriata (Acari: Ixodidae). Parasitol. Res. 84, 478-484.

Marchoux, E., Salimbeni, A., 1903. La Spirillose des Poules. Ann. L'Institute Pasteur 17, 569-580.

Nóbrega, P., Reis, A.S., 1947. O diagnóstico da espiroquetose aviária em animais mortos. Arq. Inst. Biol. (Sao Paulo) 18, 91-96.

Nava, S., Lareschi, M., Mangold, A.J., Guglielmone, A.A., 2004. Registros de garrapatas de importancia médico-veterinaria detectadas ocasionalmente en la Argentina. Rev. FAVE - Ciencias Vet. 3 (1-2).

Nava, S., Lareschi, M., Rebollo, C., Benítez Usher, C., Beati, L., Robbins, R.G., Durden, L.A., Mangold, A.J., Guglielmone, A.A., 2007. The ticks (Acari: Ixodida: Argasidae, Ixodidae) of Paraguay. Ann. Trop. Med. Parasitol. 101, 255-270. http://dx.doi.org/ 10.1179/136485907x176319.

Need, J.T., Dale, W.E., Keirans, J.E., Dasch, G.A., 1991. Annotated list of ticks (Acari:
Ixodidae, Argasidae) reported in Peru: distribution, hosts, and bibliography. J. Med. Entomol. 28, 590-597.

Neumann, L.G., 1904. Notes sur les Ixodidés. III. Arch. Parasitol. 9, 225-241.

Nuttall, G.H.F., Warburton, C., Cooper, W.F., Robinson, L.E., 1908. Ticks. A Monograph of the Ixodoidea. Part I Argasidae. Cambridge University Press, London.

Oken, L., 1818. Sogenannte giftige Wanze in Persien. Isis 9, 1567-1570.

Osorno-Mesa, E., 1940. Las Garrapatas de la República de Colombia. Rev. Acad. Colomb. Ciencias Exactas Fis. Quim. Nat. 4, 6-24.

Pader, V., Buniak, J.N., Abdissa, A., Adamu, H., Tolosa, T., Gashaw, A., Cutler, R.R., Cutler, S.J., 2012. Candidatus Rickettsia hoogstraalii in Ethiopian Argas persicus ticks. Ticks Tick Borne Dis. 3, 338-345. http://dx.doi.org/10.1016/j.ttbdis.2012.10.021.

Pantaleoni, R.A., Baratti, M., Barraco, L., Contini, C., Cossu, C.S., Filippelli, M.T., Loru, L., Romano, M., 2010. Argas (Persicargas) persicus (Oken, 1818) (Ixodida: Argasidae) in sicily with considerations about its Italian and west-Mediterranean distribution. Parasite 17, 349-355. http://dx.doi.org/10.1051/parasite/2010174349.

Petney, T.N., Andrews, R.H., McDiarmid, L.A., Dixon, B.R., 2004. Argas persicus sensu stricto does occur in Australia. Parasitol. Res. 93, 296-299. http://dx.doi.org/10. 1007/s00436-004-1141-5.

Porter, C.E., 1928. Notas de parasitología. V. sobre argas persicus en calama.pdf. Rev. Chil. Hist. Nat. 32, 325-327.

Quantum GIS Devolpment Team, 2016. Quantum GIS Geographic Information System. Open Source Geospatial Foundation Project.

Rehácek, J., Urvölgyi, J., Kovácová, E., 1977. Massive occurrence of rickettsiae of the spotted fever group in fowl tampan, Argas persicus, in the Armenian S.S.R. Acta Virol. $21,431-438$.

Rios, N.E., Bart, H.L., 2010. GEOLocate (Version 3.21).

Rohr, C.J., 1909. Estudos Sobre Ixódidas Do Brasil (Trabalho Do Instituto Oswaldo Cruz). Gomes, Irmão \& C., Rio de Janeiro, Brazil. http://dx.doi.org/10.5962/bhl.title. 84572.

Rubel, F., Brugger, K., Haslinger, K., Auer, I., 2017. The Climate of the European Alps: Shift of Very High Resolution Köppen-Geiger Climate Zones 1800-2100, vol. 26. pp. 115-125. http://dx.doi.org/10.1127/metz/2016/0816.

Sangioni, L.A., Horta, M.C., Vianna, M.C.B., Gennari, S.M., Soares, R.M., Galvão, M.A.M., Schumaker, T.T.S., Ferreira, F., Vidotto, O., Labruna, M.B., 2005. Rickettsial infection in animals and Brazilian spotted fever endemicity. Emerg. Infect. Dis. 11, 265-270. http://dx.doi.org/10.3201/eid1102.040656.

Santos-Dias, J., 1958. Notes on various ticks (Acarina: Ixodoidea) in collection at some entomological institutes in Paris and London. An. Ins. Med. Trop. 15, 459-463.

Santos, H.A., Angelo, I.D.C., Franque, M.P., Vashist, U., Duarte, A.F., Baldani, C.D., Thomé, S.M.G., Faccini, J.L.H., Massard, C.L., 2010. The influence of the fasting period on the number of nymphal instars and on the sex ratio of Argas (Persicargas) miniatus (Acari: Argasidae). Rev. Bras. Parasitol. Vet. 19, 164-168. http://dx.doi.org/ 10.1590/S1984-29612010000300007.

Sonenshine, D.E., Clifford, G.M., Kohls, G.M., 1962. The identification of larvae of the genus Argas (Acarina: Argasidae). Acarologia 4, 193-214.

Sonenshine, D.E., 1962. External anatomy of the bat tick Ornithodoros kelleyi Cooley and Kohls (Acarina: Argasidae). J. Parasitol. 48, 470-485.

Stefanov, V., Matev, I., Balimezov, I., 1975. Role of ticks of the species Argas persicus Oken 1818 , in the epizootology of pullorum disease in birds. [Article in Bulgarian]. Vet. Med. Nauki 12, 45-50.

Tamura, K., Peterson, D., Peterson, N., Stecher, G., Nei, M., Kumar, S., 2011. MEGA5: molecular evolutionary genetics analysis using maximum likelihood, evolutionary distance, and maximum parsimony methods. Mol. Biol. Evol. 28, 2731-2739. http:// dx.doi.org/10.1093/molbev/msr121.

Thompson, J.D., Higgins, D.G., Gibson, T.J., 1994. CLUSTAL W: improving the sensitivity of progressive multiple sequence alignment through sequence weighting, positionspecific gap penalties and weight matrix choice. Nucleic Acids Res. 22, 4673-4680. http://dx.doi.org/10.1093/nar/22.22.4673.

Venzal, J.M., Castro, O., Cabrera, P.A., de Souza, C.G., Guglielmone, A.A., 2003. Las garrapatas de Uruguay: especies, hospedadores, distribución e importancia sanitaria. Vet $30,17-28$.

Vigueras, J.P., 1934. On the ticks of cuba, with description of a new species Amblyomma torrei, from Cyclura macleayi Gray. Psyche A J. Entomol. 41, 13-18. http://dx.doi. $\operatorname{org} / 10.1155 / 1934 / 32624$.

Vogelsang, E.G., Cordero, E.H., 1940. Las Garrapatas (Ixodidae) de Venezuela. Rev. Med. Vet. Parasitol. 2, 71-75.

Vogelsang, E.G., Dias, J.A.T., 1953. Nueva contribucion al estudio de la fauna ixodológica en Venezuela. Rev. Med. Vet. Parasitol. 12, 63-89.

Vogelsang, E.G., 1928. Garrapatas (Ixodidae) del Uruguay: Boletín del Inst. Clínica Quirúrgica Buenos Aires 4, 668-670.

Zaher, M.A., Soliman, Z.R., Diab, F.M., 1977. An experimental study of Borrelia anserina in four species of Argas ticks. 2. Transstadial survival and transovarial transmission. Z. Parasitenkd. 53, 213-223. 